\title{
Tiechanshan-Tunghsiao anticline earthquake analysis: Implications for northwestern Taiwan potential carbon dioxide storage site seismic hazard
}

\author{
Ruey-Juin Rau *, Chia-Hsun Yang, and Kenn-Ming Yang
}

Department of Earth Sciences, National Cheng Kung University, Tainan City, Taiwan

Article history:

Received 13 March 2012

Accepted 21 September 2015

Keywords:

Seismicity and tectonics, Focal mechanisms and stress, Earthquake potential, Carbon capture and storage, Tiechanshan-Tunghsiao anticline

Citation:

Rau, R.-J., C.-H. Yang, and K.-M. Yang, 2017: Tiechanshan-Tunghsiao anticline earthquake analysis: Implications for northwestern Taiwan potential carbon dioxide storage site seismic hazard. Terr. Atmos. Ocean. Sci., 28, 239-246, doi: 10.3319/ TAO.2015.09.21.01(GSC)

\begin{abstract}
We analyze the seismicity and earthquake focal mechanisms beneath the Tiechanshan-Tunghsiao (TCS-TH) anticline over the last two decades for seismic hazard evaluation of a potential carbon dioxide storage site in northwestern Taiwan. Seismicity in the TCS-TH anticline indicates both spatial and temporal clustering at a depth range of $7-12 \mathrm{~km}$. Thirteen $3.0 \leq \mathrm{M}_{\mathrm{L}} \leq 5.2$ earthquake focal mechanisms show a combination of thrust, strike-slip, and normal faulting mechanisms under the TCS-TH anticline. A $1992 \mathrm{M}_{\mathrm{L}} 5.2$ earthquake with a focal depth of $\sim 10 \mathrm{~km}$, the largest event ever recorded beneath the TCS-TH anticline during the last two decades, has a normal fault mechanism with the T-axis trending NNE-SSW and nodal planes oriented NNW-SSE, dipping either gently to the NNE or steeply to the SSW. Thrust fault mechanisms that occurred with mostly E-W or NWW-SEE striking P-axes and strike-slip faulting events indicate NWW-SEE striking P-axes and NNE-SSW trending T-axes, which are consistent with the regional plate convergence direction. For the strike-slip faulting events, if we take the N-S or NNW-SSE striking nodal planes as the fault planes, the strike-slip faults are sinistral motions and correspond to the Tapingting fault, which is a strike-slip fault reactivated from the inherited normal fault and intersects the Tiechanshan and Tunghsiao anticlines.
\end{abstract}

\section{INTRODUCTION}

The Tiechanshan-Tunghsiao (TCS-TH) anticline is one of the kilometer-scale folded structures considered as potential sites for underground carbon dioxide storage in northwestern Taiwan (Fig. 1). Understanding the seismic hazard presented by a carbon dioxide storage site is one of the vital components for subsurface storage reservoir safety considerations. Northwestern Taiwan, situated at the northernmost part of the active fold-thrust belt, is located at the diminishing collision zone (Angelier et al. 1986; Shyu et al. 2005; Rau et al. 2008) (Fig. 1). As a consequence, the earthquakes recorded during the last two decades are rather diffuse in response to the low crustal strain rate in this part of Taiwan (Rau et al. 2008; Ching et al. 2011). In spite of the lack of background seismicity, northwestern Taiwan experienced a devastating M 7.1 Hsinchu-Taichung earthquake sequence in 1935 (Fig. 1). Thus, a detailed earthquake analysis and seismic hazard assessment of the potential carbon dioxide

\footnotetext{
* Corresponding author

E-mail:raurj@mail.ncku.edu.tw
}

storage sites in northwestern Taiwan is even more important for underground storage reservoir safety evaluation.

The TCS-TH anticline is the site of the largest gas field in Taiwan. This gas field contributed more than $60 \%$ of the total hydrocarbon production on the island before 2003 . Since 2003, it has been regulated as an underground natural gas storage site (Tzeng et al. 2003). The TCS-TH anticline is characterized by a gently-folded and symmetrical structure, in contrast with the steeply-folded and symmetrical Chuhuangkeng anticline to the east (Figs. 1 and 2). Studies based on seismic reflection data showed that the Paleogene and Miocene strata beneath the TCS-TH anticline and its neighboring areas are offset by the inherited high-angle normal faults (Hsiao 1982) (Fig. 2). This indicated that both inversion tectonics and basement-involved deformation are incorporated into the frontal thrust wedge in northwestern Taiwan (Mouthereau et al. 2002; Lacombe et al. 2003; Mouthereau and Lacombe 2006; Yang et al. 2006) (Fig. 2). As such, one may ask what the seismic activity of these regions. Is there any evidence showing reactivation of the preexisting normal fault beneath the anticline? Furthermore, by 
considering the seismogenic structure in this region, what is the maximum possible earthquake that may occur in the TCS-TH anticline?

The focal mechanisms of small-to-moderate-sized earthquakes occurring before 1995 in Taiwan have been investigated by Rau and Wu (1998). However, the correlations between hypocenters and structure and their tectonic implications remain unclear. We evaluate seismicity and determine the focal mechanisms for earthquakes occurring during the last two decades to examine the seismogenic structures and the stress state in the TCS-TH anticline.
Two decades of seismicity is a snapshot in the geological history of the study area. However, by studying the shortterm earthquake behavior we can understand the earthquake characteristics and style of earthquake faulting in an area. If we combine this information with the understanding of the geological structures, we may estimate the possible extension of the fault at depth and also its maximum possible earthquake magnitude. We shall demonstrate that the style of earthquake faulting shows a mixture of thrust, strike-slip and normal faulting mechanisms under the TCS-TH anticline. The $1992 \mathrm{M}_{\mathrm{L}} 5.2$ earthquake sequences occurring in

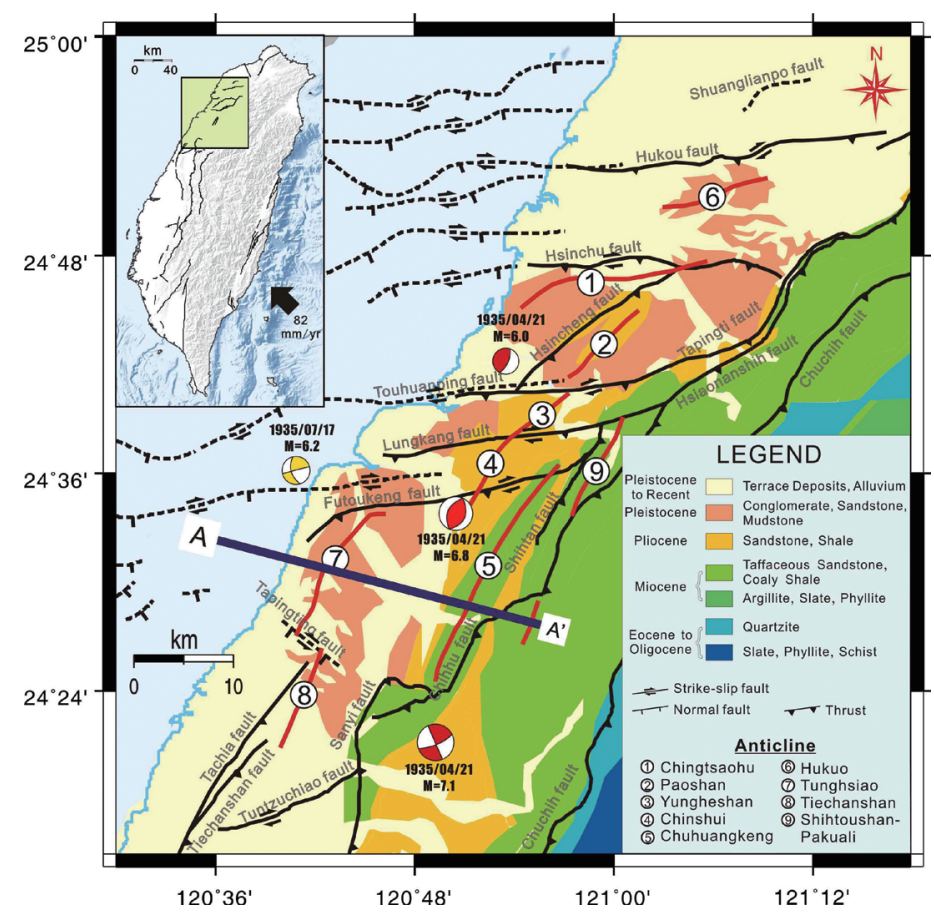

Fig. 1. Geologic map of northwestern Taiwan showing fault and folded structures. Locations of 1935 M 7.1 Hsinchu-Taichung earthquake sequences are marked by their respective focal mechanisms in lower-hemisphere, equal-area projection. Confirmed faults are shown as solid black lines and inferred or concealed faults are indicated by dashed black lines. The insert in the upper left shows a map of Taiwan with shaded relief. Active faults are shown in black lines. The relative motion vector between the Philippine Sea plate and the Eurasian plate is shown by the arrow (Yu et al. 1997). A black rectangle denotes the study area. The geological map of northwestern Taiwan is modified from Chen (2000), Lin et al. (2000), and Yang et al. (2006). (Color online only)

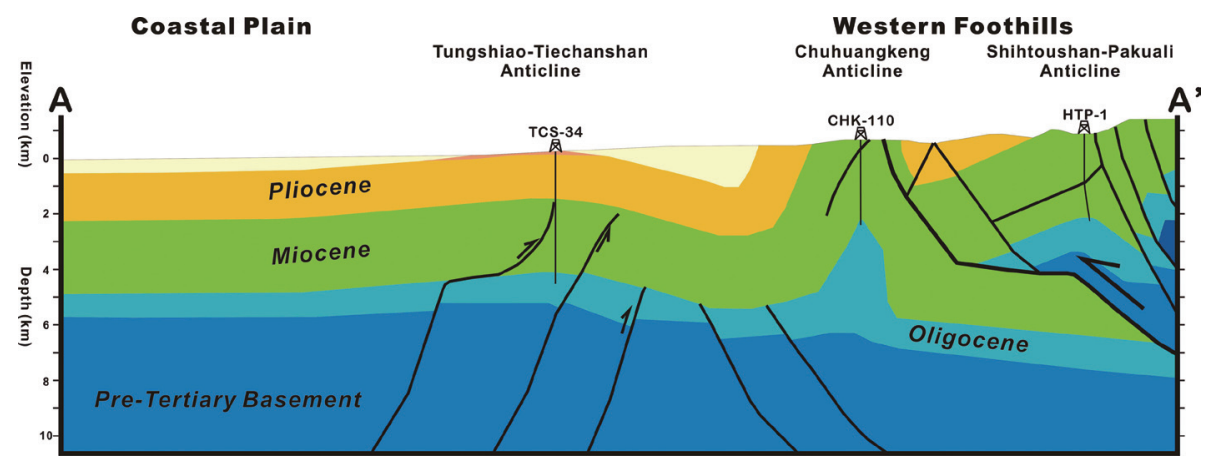

Fig. 2. Geological cross section AA' across the TCS-TH anticline, showing associated structures. The section location is shown in Fig. 1. The section is modified from Hsiao (1982) and Mouthereau and Lacombe (2006). (Color online only) 
between the Tiechanshan and Tunghsiao anticlines with the normal fault motion main shock may indicate reactivation of the inherited normal fault at depth (Fig. 1).

\section{TECTONIC SETTING OF THE TCS-TH ANTICLINE}

The TCS-TH anticline, along with other folded structures in northwestern Taiwan are products of the Taiwan arc-continent collision that began about 4 - $5 \mathrm{Ma}$ (e.g., Teng 1979; Suppe 1981, 1984; Chi and Huang 1981; Yang et al. 2006) (Fig. 1). Where the anticline is situated northwestern Taiwan is considered a basin-controlled salient judging from the along-strike variation in the Neogene basin thickness (Lacombe et al. 2003) located at the northernmost end of the active contraction zone in Taiwan (Shyu et al. 2005; Ching et al. 2011). The TCS-TH anticline creation is dated $\sim 0.5 \mathrm{Ma}$ based on the ages of the Pleistocene Toukoshan formation growth strata and the tilted terraces on the fold (Mouthereau and Lacombe 2006).

The TCS-TH anticline is a 13-km-long, 4-km-wide; NE-SW-trending gently-folded structure (Fig. 1). Structural analysis and seismic reflection study integration suggests that the Paleogene and Miocene strata beneath the anticline have been displaced by normal faults and some inherited NWWSEE-trending high-angle normal faults may have been reactivated as strike-slip faults (Hsiao 1982) (Figs. 1 and 2). A suspected $\sim 7.5 \mathrm{~km}$ NWW-SEE-trending sinistral strike-slip fault (the Tapingting fault) may have separated the Tiechanshan and Tunghsiao anticlines (Chang 1994; Tzeng et al. 2003) (Fig. 1). This indicates that, as the mountain front of the northwestern Taiwan fold-thrust belt, fault reactivation and basement-involved tectonics are the important mechanisms in the TCS-TH anticline development (Mouthereau et al. 2002; Lacombe et al. 2003; Mouthereau and Lacombe 2006; Yang et al. 2006).

\section{EARTHQUAKE DATA ANALYSES}

We analyzed the earthquake data in the TCS-TH anticline area recorded after 1991 . That year a previous 25 -station TTSN (Taiwan Telemetered Seismographic Network) was merged into the CWBSN (Central Weather Bureau Seismic Network) forming a 75 seismic station network (Shin 1993). More than $500 \mathrm{M}_{\mathrm{L}} \geq 3.0$ earthquakes recorded by the CWBSN from 1991 to 2010 were selected for northwestern Taiwan. These earthquakes were relocated using a previously published 3D velocity model (Rau and Wu 1995) (Fig. 3). The average RMS residual was $0.16 \mathrm{~s}$ for the relocated $\mathrm{M}_{\mathrm{L}} \geq 3.0$ hypocenters with observations between 10 and 46 stations, compared with RMS residual of $0.25 \mathrm{~s}$ for locations in the original catalogue. The relocated seismicity distributed mainly in the Western Foothills and the Hsuehshan Range, which are mostly 1999 M $_{w}$ 7.6 Chi-Chi aftershocks. Seismicity in the other parts of northwestern Taiwan appears to be scattered, whereas a cluster of $32 \mathrm{M}_{\mathrm{L}} \geq 3.0$

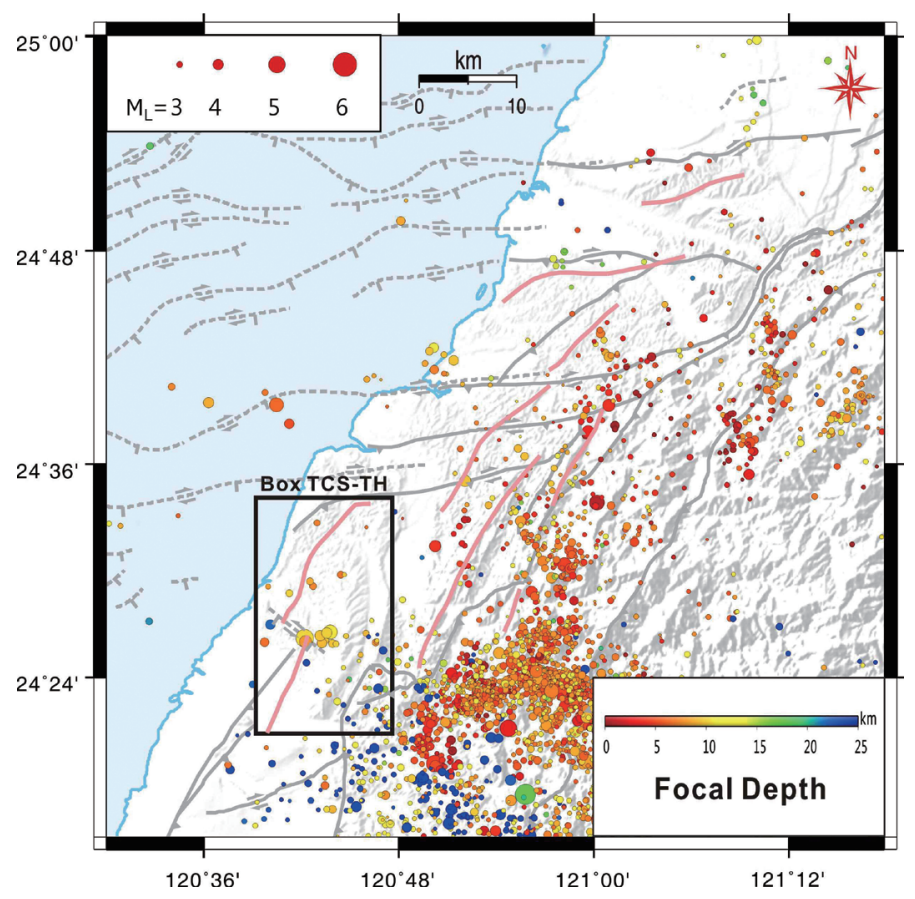

Fig. 3. Map of northwestern Taiwan showing epicentral locations of $\mathrm{M}_{\mathrm{L}} \geq 3.0$ earthquakes (circles) occurring between 1 January 1991 and 31 December 2010. The earthquakes are relocated using the 3D velocity model. The epicenters are coded for both magnitude (scale at upper left) and focal depth (scale at bottom right). Descriptions of the geological structures are the same as those in Fig. 1. The black rectangular box TCS-TH denotes the study area shown in Fig. 4. (Color online only) 
events with a depth range of $7-12 \mathrm{~km}$ was concentrated beneath the TCS-TH anticline center (Fig. 4).

We determined focal mechanisms for $\mathrm{M}_{\mathrm{L}} \geq 3.0$ earthquakes following the approach of Rau et al. (1996) by incorporating first motions and SH/P amplitude ratios (Snoke et al. 1984). The events were selected based on the following criteria: (1) location errors less than $2 \mathrm{~km}$ horizontally and $3 \mathrm{~km}$ vertically; (2) more than $11 \mathrm{P}$-wave polarity readings available and the maximum number of polarity inconsistencies allowed is 2; and (3) more than five SH/P amplitude ratios can be obtained and the maximum RMS error and number of SH/P amplitude ratio errors allowed are 0.6 and 2 , respectively. A total of 13 focal mechanisms for smallto-moderate-sized events $\left(3.0 \leq \mathrm{M}_{\mathrm{L}} \leq 5.2\right)$ occurred in the TCS-TH anticline area was obtained in the present study (Fig. 4 and Table 1).

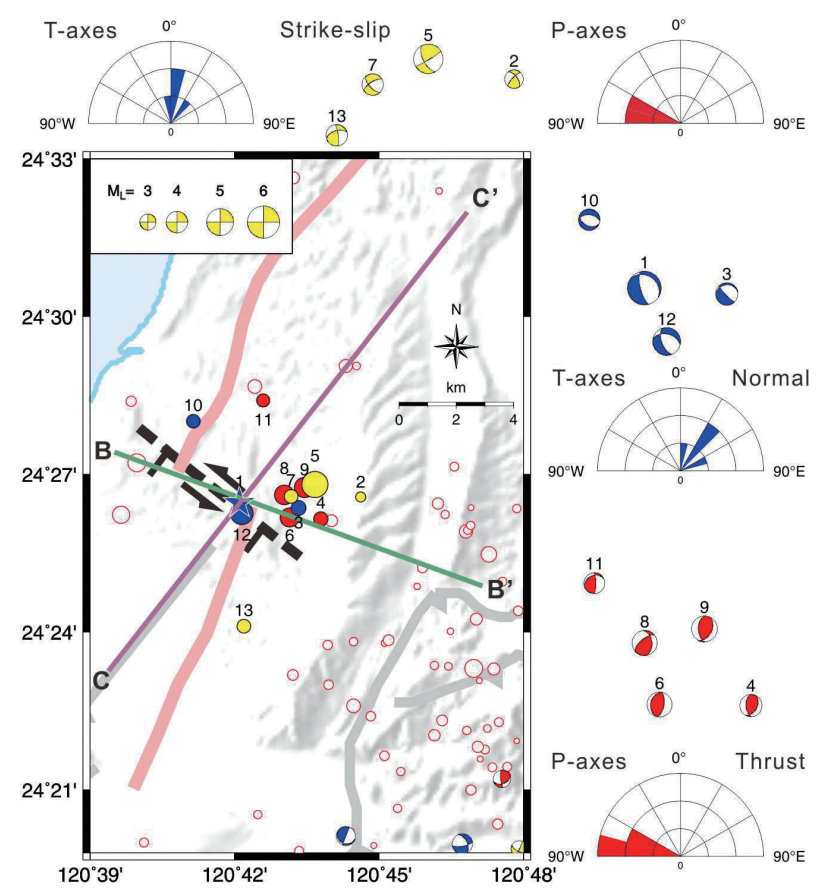

Fig. 4. Map of the TCS-TH anticline area showing $32 \mathrm{M}_{\mathrm{L}} \geq 3.0$ epicentral locations. Thirteen $3.0 \leq \mathrm{M}_{\mathrm{L}} \leq 5.2$ events are shown with their focal mechanisms. On each focal sphere the shaded area represents the compressive quadrant and the white area represents the dilatational quadrant. The solutions are plotted on the lower hemisphere, equal-area projection and are coded for magnitude (scale at upper left). The earthquake focal mechanisms are shown as red color for thrust, yellow for strike-slip, and blue for normal fault mechanisms. The P-axes and/or T-axes orientations of the three types of focal mechanisms are shown in rose diagrams. Descriptions of the geological structures are the same as those in Fig. 1. Cross sections BB' - CC' indicate the section locations of profiles shown in Figs. 6 and 7. (Color online only)

Table 1. Source parameters of 13 earthquakes used in this study.

\begin{tabular}{|c|c|c|c|c|c|c|c|c|c|c|c|c|c|c|c|c|c|c|}
\hline NO & rmoday & hrmin & Lat $\left({ }^{\circ} \mathbf{N}\right)$ & Lon $\left({ }^{\circ} \mathbf{E}\right)$ & depth & mag & \multicolumn{3}{|c|}{ Plane $1(s, d, r)$} & \multicolumn{3}{|c|}{ Plane $2(s, d, r)$} & \multicolumn{2}{|c|}{$\mathbf{P}(\mathbf{t}, \mathbf{p})$} & \multicolumn{2}{|c|}{$T(t, p)$} & \multicolumn{2}{|c|}{$B(t, p)$} \\
\hline 1 & 19920420 & $16: 16$ & 24.45 & 120.71 & 10.25 & 5.2 & 165 & 71 & -74 & 304 & 25 & -128 & 99 & 61 & 243 & 24 & 340 & 15 \\
\hline 2 & 19920420 & 10.01 & $24.4 J$ & 120.13 & 3.01 & 3.0 & 323 & 0 & 17 & 220 & 73 & 149 & 276 & ( & 180 & 37 & 18 & 55 \\
\hline 3 & 19920420 & $16: 33$ & 24.45 & 120.73 & 9.56 & 3.5 & 136 & 80 & -75 & 258 & 18 & -147 & 64 & 53 & 213 & 33 & 313 & 15 \\
\hline 4 & 19920420 & $16: 48$ & 24.45 & 120.74 & 9.56 & 3.4 & 178 & - & 71 & 27 & 42 & 113 & 281 & 5 & 30 & 74 & 190 & 15 \\
\hline 5 & 19920421 & $13: 36$ & 24.46 & 120.73 & 10.67 & 4.6 & 152 & 61 & 6 & 59 & 85 & 150 & 109 & 16 & 12 & 24 & 230 & 60 \\
\hline 6 & 19920422 & $07: 55$ & 24.45 & 120.73 & 9.24 & 3.9 & 10 & 60 & 90 & 190 & 30 & 90 & 100 & 15 & 280 & 75 & 10 & 0 \\
\hline 7 & 19920422 & $19: 59$ & 24.45 & 120.73 & 10.16 & 3.3 & 137 & 64 & -24 & 238 & 68 & -152 & 99 & 35 & 7 & 3 & 272 & 55 \\
\hline 8 & 19920426 & $13: 59$ & 45 & 12 & 9.48 & 3.9 & 35 & 41 & 41 & 231 & 64 & 124 & 297 & 13 & 186 & 57 & 35 & 30 \\
\hline 9 & 19920429 & $16: 54$ & 24.46 & 120.73 & 08 & 4.1 & 17 & 52 & 原 & 27 & 42 & 113 & 281 & 列 & 30 & 74 & 190 & 15 \\
\hline 10 & 19931206 & $13: 21$ & 2 & & 10.02 & 3.3 & 11 & . & -75 & 27 & 51 & -103 & 131 & 79 & 15 & 5 & 284 & 10 \\
\hline 11 & 19960724 & $16: 47$ & 2 & & 7 & 3.3 & 35 & 76 & 64 & 24 & 29 & 151 & 109 & 27 & 239 & 52 & 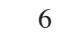 & 25 \\
\hline 12 & 19970520 & $14: 55$ & 24.45 & 120.71 & 7.96 & 4.3 & 15 & 00 & -55 & 28 & 45 & -135 & 120 & 59 & 224 & 9 & 319 & 30 \\
\hline 13 & 19971022 & $21: 45$ & 24.41 & 120.71 & 25.90 & 3.3 & 352 & 77 & 38 & 252 & 53 & 164 & 117 & 16 & 219 & 36 & 8 & 50 \\
\hline
\end{tabular}




\section{SEISMICITY AND EARTHQUAKE FOCAL MECHANISMS}

The earthquakes that occurred in the TCS-TH anticline were clustered in both space and time (Figs. 4,5, and Table 1). Seismicity concentrated mainly in the center of the anticline at a depth range of $7-12 \mathrm{~km}$, in between the Tiechanshan and Tunghsiao anticlines where the suspected NWW-SEEtrending sinistral strike-slip fault is located (Hsiao 1982; Chang 1994; Tzeng et al. 2003). Based on the earthquake magnitude-frequency histogram, the TCS-TH anticline seismicity is dominated by an earthquake sequence that occurred in April 1992 with an $\mathrm{M}_{\mathrm{L}} 5.2$ main shock (Fig. 5).

The focal mechanisms of 13 earthquakes show a mixture of thrust, strike-slip and normal faulting mechanisms under the TCS-TH anticline (Fig. 4 and Table 1). Five thrust fault mechanisms (events 4, 6, 8, 9, and 11) with mostly NWWSEE striking P-axes occurred roughly along a $40^{\circ}$ east-dipping plane at the upper-to-mid crustal level of $7-10 \mathrm{~km}$ (Figs. 4 and 6). The $1992 \mathrm{M}_{\mathrm{L}} 5.2$ earthquake (event 1) has a normal fault mechanism with the T-axis trending NNESSW and nodal planes oriented NNW-SSE, dipping either gently to the NNE or steeply to the SSW (Figs. 4 and 7). Three other normal fault mechanism events (events 3, 10,

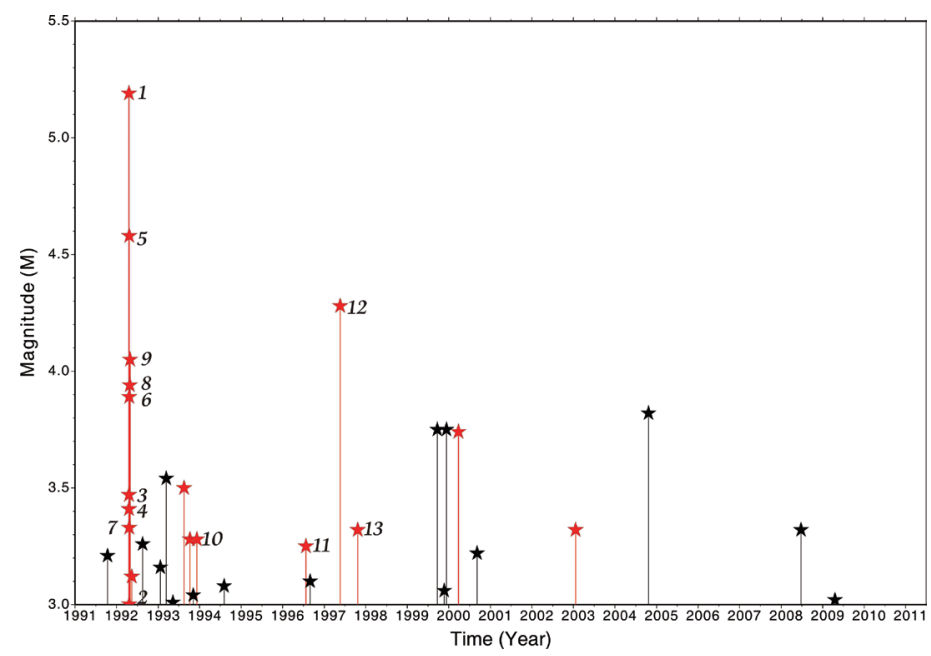

Fig. 5. Local magnitudes of the $\mathrm{M}_{\mathrm{L}} \geq 3.0$ earthquakes occurring in the TCS-TH anticline shown as a function of time. Red colors indicate that events occurred within the TCS-TH anticline area (west of the Sanyi fault) and black colors are the events that occurred east of the Sanyi fault (Fig. 4). (Color online only)

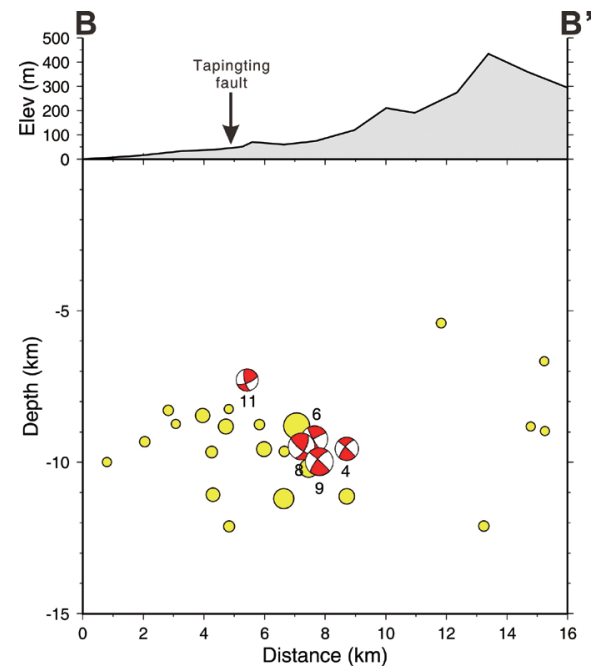

Fig. 6. Map of cross section B - B' perpendicular to the strike of the TCS-TH anticline, showing distribution of thrust fault mechanisms plotted in back-hemisphere projection. The cross section location is indicated in Fig. 4. The topography corresponding to the profile is shown at the top of the cross section. (Color online only)

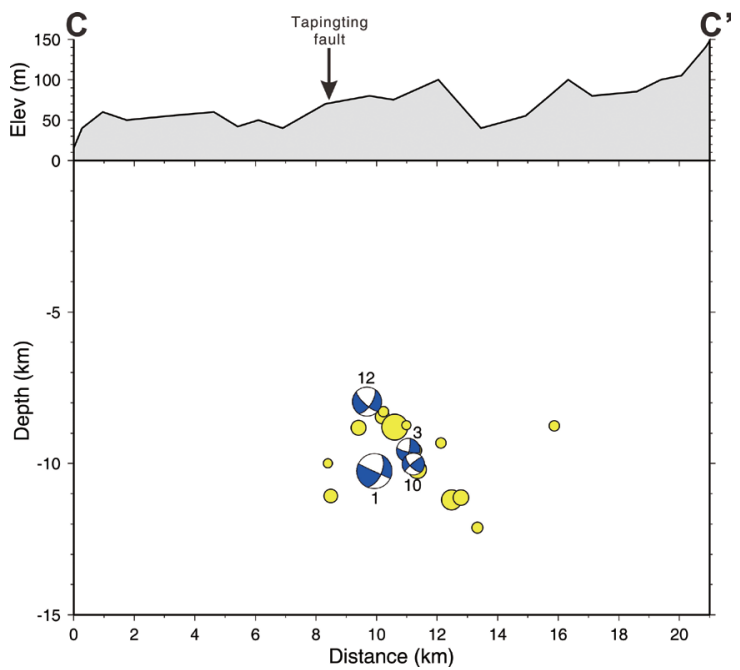

Fig. 7. Map of cross section $\mathrm{C}-\mathrm{C}^{\prime}$ perpendicular to the strike of the suspected Tapingting fault, showing distribution of normal fault mechanisms plotted in back-hemisphere projection. The cross section location is indicated in Fig. 4. The topography corresponding to the profile is shown at the top of the cross section. (Color online only) 
and 12) also show nodal planes oriented NNW-SSE with the NNE-SSW striking T-axes at the upper-to-mid crustal level of 7 - $10 \mathrm{~km}$ (Figs. 4 and 7). Strike-slip faulting events (events 2, 5, 7, and 13) indicate NWW-SEE striking P-axes and NNE-SSW trending T-axes concentrated at $\sim 10 \mathrm{~km}$ mid-crustal level, except for event 13 (Fig. 4). If we take the $\mathrm{N}-\mathrm{S}$ or NNW-SSE striking nodal planes as the fault planes, the strike-slip faults are sinistral motions.

\section{DISCUSSION}

The most prominent earthquake that ever occurred in the TCS-TH anticline for the last two decades is the 1992 $\mathrm{M}_{\mathrm{L}} 5.2$ event oriented NNW-SSE with a depth of $10 \mathrm{~km}$ right under the middle of the anticline (Fig. 4). It shows a normal faulting dominated mechanism with the T-axis trending NNE-SSW, which is roughly parallel to the strike of the folded structure, indicating extension along the strike of the northwestern Taiwan fold-thrust belt. A normal fault located in the foreland region usually relates to the flexure of convex upper crust of a flexed plate (Bradley and Kidd 1991) which predicts extension perpendicular to the strike of the orogen. This apparently contradicts the observation we found here. Furthermore, in the tectonic regime of northwestern Taiwan, the question we face now is how to reduce the collision-related NWW-SEE trending $\sigma_{1}$ until it is less than the overburden pressure and let $\sigma_{3}$ oriented NNE-SSW and parallel to the orogen. Situated at the waning collision zone of the northwestern Taiwan mountain front, it is not difficult to decrease the collision intensity where the 1992 event is located. Let $\sigma_{3}$ orient NNE-SSW and parallel to the orogen, one plausible way is to create an orogen-parallel flow in the viscous lower crust and upper mantle, which in turn provides a mechanism for orogen-parallel extension. This explanation has been applied to the 1994 M 6.5 Taiwan Strait earthquake (Kao and Wu 1996), and such a lateral extrusion mechanism is not uncommon in the oblique convergence tectonic regime and is also supported by the seismic anisotropy study results in Taiwan (Rau et al. 2000).

Three events (events 2, 5, and 7) show strike-slip fault mechanisms with a NWW-SEE striking P-axis and a NNE-SSW trending T-axis concentrated at the $10 \mathrm{~km}$ mid-crustal level (Fig. 4). The stress regime is consistent with the regional NWW-SEE plate convergence direction. If we take the N-S or NNW-SSE striking nodal planes as the fault planes, the strike-slip faults are sinistral motions, corresponding to the suspected Tapingting fault proposed from structural analyses (Hsiao 1982). The seismic faulting with sinistral motion further demonstrates reactivation of the inherited normal fault as the strike-slip fault under the TCS-TH anticline.

Earthquakes under the TCS-TH anticline show a mixture of thrust, strike-slip, and normal faulting mechanisms (Fig. 4). Both thrust and strike-slip faulting events consis- tent with a thrust/strike-slip faulting regime with $\sigma_{1}$ trending NWW-SEE and $\sigma_{3}$ oriented NNE-SSW in the regional plate convergence direction, indicating collision-related stress. With the addition of the stated above NNE-SSW extension caused by orogen-parallel flow in the viscous lower crust and upper mantle, both oblique convergence and lateral extrusion mechanisms contribute together to the tectonic regime under the TCS-TH anticline. Under such dual mechanisms and with the aid of a low strain rate, stress permutes more easily in the TCS-TH anticline. These elements create both a complex style of earthquake faulting and spatial and temporal clustering in the seismicity of this area.

Based on earthquake analyses it appears that the Tapingting fault is an active sinistral strike-slip fault reactivated from the inherited normal fault under the TCS-TH anticline. Considering $7.5 \mathrm{~km}$ as the rupture length of the Tapingting fault (Chang 1994; Tzeng et al. 2003), based on the empirical relationship between the moment magnitude and surface rupture length (Wells and Coppersmith 1994), the maximum potential earthquake for the Tapingting fault is $\sim \mathrm{M}_{\mathrm{w}}$ 6.1. The maximum possible earthquake may be moderate and the Tapingting fault may not have reached the surface, however the effects of the designated earthquake need to be evaluated for subsurface storage reservoir safety considerations. Furthermore, the reactivation of inherited normal faults under the other folded structures in northwestern Taiwan must be considered as well if this area is considered as a potential site for underground carbon dioxide storage.

\section{CONCLUSIONS}

Seismicity analysis conducted on the TCS-TH anticline over the last two decades indicates that hypocenters concentrate at $7-12 \mathrm{~km}$ depth, the upper-mid crustal level beneath the middle of the anticline. Earthquake focal mechanisms show a mixture of thrust, strike-slip and normal faulting mechanisms with the $\mathrm{P}$ - and $\mathrm{T}$-axes roughly consistent with the regional NWW-SEE convergence direction. A $1992 \mathrm{M}_{\mathrm{L}}$ 5.2 normal faulting event with orogen-parallel $\mathrm{T}$-axis suggests orogen-parallel flow in the viscous lower crust and upper mantle, providing a mechanism for orogen-parallel extension. Strike-slip faulting mechanisms may demonstrate inherited normal fault reactivation as the strike-slip fault under the TCS-TH anticline. Complex earthquake focal mechanisms indicate that both oblique convergence and lateral extrusion contribute together to the tectonic regime under the TCS-TH anticline. Based on the empirical relationship between the moment magnitude and surface fault rupture length, the maximum potential earthquake for the Tapingting fault is $\sim \mathrm{M}_{\mathrm{w}} 6.1$.

Acknowledgements We thank the Seismological Center of the Central Weather Bureau of Taiwan for the earthquake data. Figures were generated using the Generic Mapping 
Tools (GMT), developed by Wessel and Smith (1991). This research was partially supported by Taiwan NSC grant 1002116-M-006-015.

\section{REFERENCES}

Angelier, J., E. Barrier, and H. T. Chu, 1986: Plate collision and paleostress trajectories in a fold-thrust belt: The Foothills of Taiwan. Tectonophysics, 125, 161-178, doi: 10.1016/0040-1951(86)90012-0. [Link]

Bradley, D. C. and W. S. F. Kidd, 1991: Flexural extension of the upper continental crust in collisional foredeeps. Geol. Soc. Am. Bull., 103, 1416-1438, doi: 10.1130/00 16-7606(1991)103<1416:FEOTUC>2.3.CO;2. [Link]

Chang, H. C., 1994: Geological map of Taiwan scale 1:50,000, Tachia. Central Geological Survey, MOEA, Taiwan.

Chen, C. H., 2000: Geologic Map of Taiwan scale 1:500,000. Central Geological Survey, MOEA, Taiwan.

Chi, W. R. and H. M. Huang, 1981: Nannobiostratigraphy and paleoenvironments of the late Neogene sediments and their tectonics implications in the Miaoli area, Taiwan. Petrol. Geol.Taiwan, 18, 111-129.

Ching, K. E., R. J. Rau, K. M. Johnson, J. C. Lee, and J. C. Hu, 2011: Present-day kinematics of active mountain building in Taiwan from GPS observations during 1995-2005. J. Geophys. Res., 116, B09405, doi: 10.1029/2010JB008058. [Link]

Hsiao, P. T., 1982: Relationship between the faulting of the Late Miocene period and the migration of petroleum in northwestern Taiwan. 1982 Annual and 20th Anniversary Convention of the Chinese Petroleum Institute, Petroleum Geology Session, 1-9. (in Chinese)

Kao, H. and F. T. Wu, 1996: The 16 September 1994 earthquake $\left(m_{b}=6.5\right)$ in the Taiwan Strait and its tectonic implications. Terr. Atmos. Ocean. Sci., 7, 13-29, doi: 10.3319/TAO.1996.7.1.13(T). [Link]

Lacombe, O., F. Mouthereau, J. Angelier, H. T. Chu, and J. C. Lee, 2003: Frontal belt curvature and oblique ramp development at an obliquely collided irregular margin: Geometry and kinematics of the NW Taiwan foldthrust belt. Tectonics, 22, doi: 10.1029/2002TC001436. [Link]

Lin, C. W., H. C. Chang, S. T. Lu, T. S. Shih, and W. J. Huang, 2000: An introduction to the active faults of Taiwan, with explanatory text of the active fault map of Taiwan, scale 1:500,000. Special Publication of the Central Geological Survey No. 13, Central Geological Survey, MOEA, Taiwan. (in Chinese with English abstract)

Mouthereau, F. and O. Lacombe, 2006: Inversion of the Paleogene Chinese continental margin and thickskinned deformation in the Western Foreland of Taiwan. J. Struct. Geol., 28, 1977-1993, doi: 10.1016/j. jsg.2006.08.007. [Link]

Mouthereau, F., B. Deffontaines, O. Lacombe, and J. Angelier, 2002: Variations along the strike of the Taiwan thrust belt: Basement control on structural style, wedge geometry, and kinematics. Geol. Soc. Am. Spec. Pap., 358, 31-54, doi: 10.1130/0-8137-2358-2.31. [Link]

Rau, R. J. and F. T. Wu, 1995: Tomographic imaging of lithospheric structures under Taiwan. Earth Planet. Sci. Lett.,133,517-532,doi:10.1016/0012-821X(95)00076O. [Link]

Rau, R. J. and F. T. Wu, 1998: Active tectonics of Taiwan orogeny from focal mechanisms of small-to-moderatesized earthquakes. Terr. Atmos. Ocean. Sci., 9, 755-778, doi: 10.3319/TAO.1998.9.4.755(TAICRUST). [Link]

Rau, R. J., F. T. Wu, and T. C. Shin, 1996: Regional Network focal mechanism determination using $3 \mathrm{D}$ velocity model and $S H / P$ amplitude ratio. Bull. Seismol. Soc. Am., 86, 1270-1283.

Rau, R. J., W. T. Liang, H. Kao, and B. S. Huang, 2000: Shear wave anisotropy beneath the Taiwan orogen. Earth Planet. Sci. Lett., 177, 177-192, doi: 10.1016/ S0012-821X(00)00058-3. [Link]

Rau, R. J., K. E. Ching, J. C. Hu, and J. C. Lee, 2008: Crustal deformation and block kinematics in transition from collision to subduction: Global positioning system measurements in northern Taiwan, 1995-2005. J. Geophys. Res., 113, B09404, doi: 10.1029/2007JB005414. [Link]

Shin, T. C., 1993: The calculation of local magnitude from the simulated Wood-Anderson seismograms of the short-period seismograms in the Taiwan area. Terr. Atmos. Ocean. Sci., 4, 155-170, doi: 10.3319/ TAO.1993.4.2.155(T). [Link]

Shyu, J. B. H., K. Sieh, Y. G. Chen, and C. S. Liu, 2005: Neotectonic architecture of Taiwan and its implications for future large earthquakes. J. Geophys. Res., 110, B08402, doi: 10.1029/2004JB003251. [Link]

Snoke, J. A., J. W. Munsey, A. G. Teague, and G. A. Bollinger, 1984: A program for focal mechanism determination by combined use of polarity and SV-P amplitude ratio data. Earthquake Notes, 55.

Suppe, J., 1981: Mechanics of mountain building and metamorphism in Taiwan. Mem. Geol. Soc. China, 4, 67-89.

Suppe, J., 1984: Kinematics of arc-continent collision, flipping of subduction, and back-arc spreading near Taiwan. Mem. Geol. Soc. China, 6, 21-33.

Teng, L. S., 1979: Petrographical study of the Neogene sandstones of the Coastal Range, eastern Taiwan (I. Northern part). Acta Geol. Taiwan, 20, 129-156.

Tzeng, J. J., W. J. Wu, and T. L. Chen, 2003: Study of faultsealing problems in the structure of TCS. Petrol. Geol. Taiwan, 36, 215-240. (in Chinese)

Wells, D. L. and K. J. Coppersmith, 1994: New empirical 
relationships among magnitude, rupture length, rupture width, rupture area, and surface displacement. Bull. Seismol. Soc. Am., 84, 974-1002.

Wessel, P. and W. H. F. Smith, 1991: Free software helps map and display data. Eos, Trans., AGU, 72, 441-446, doi: 10.1029/90EO00319. [Link]

Yang, K. M., S. T. Huang, J. C. Wu, H. H. Ting, and W. W.
Mei, 2006: Review and new insights on foreland tectonics in western Taiwan. Int. Geol. Rev., 48, 910-941, doi: 10.2747/0020-6814.48.10.910. [Link]

Yu, S. B., H. Y. Chen, and L. C. Kuo, 1997: Velocity field of GPS stations in the Taiwan area. Tectonophysics, 274, 41-59, doi: 10.1016/S0040-1951(96)00297-1. [Link] 